the anti-apartheid struggle.

Although the faculty had been quietly working to promote AIDS awareness and provide adequate health care to South Africa's five million HIV-infected people, this is their most direct criticism of the president and health minister. The South African newspaper The Star called it "the strongest and most influential statement yet on official inaction against AIDS" .

UW runs an academic hospital network that cares for thousands of HIVinfected patients each day. "For years we felt it was more effective to lobby and work behind the scenes, rather than through the media, because the government tends to have a knee-jerk reaction to criticism," Max Price, dean of UW's School of the Health Sciences told Nature Medicine. "But we felt that we were not making enough progress, and that it is now necessary to make a more public campaign".

Price admits that in publicly criticizing the government they risk punitive funding cuts to the university's public university and hospitals, which depend on government support. "At this point we have exhausted all other avenues, and we simply feel that we have nothing left to lose," says Price. Other South
African universities are expected to join the cause, and the faculty at the University of Capetown followed with a similar statement.

The public statement was triggered, in part, by the refusal of the government to accept Boehringer Ingelheim's offer to provide free nevirapine for five years to South Africa. Nevirapine has been reported to cut the risk of mother-to-child transmission of HIV by up to $50 \%$. Government lawyers had previously stated that a program to administer nevirapine to all HIV-positive women would paralyze its public health

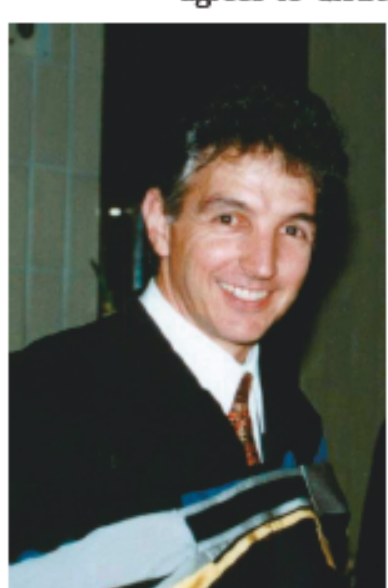

Speaking out: Max Price child HIV transmission prevention to all public health institutions."

Price says that if the government agrees to distribute nevirapine to pregsystem, as South Africa has more people living with HIV/AIDS than any other country. It also questioned the efficacy of nevirapine. "Boehringer Ingelheim's offer means that this therapy is now well in means of the government-it is now cost effective to offer nevirapine to pregnant women who are HIV-positive," says Price. Accordingly, the faculty's statement demands that the government "provide mother-to- nant women, the next step will be to call for antiretroviral treatment of all HIV-positive people. "There is great government resistance to being taken down that road," says Price. "The government claims that there are toxicity issues with the drugs, but this is just confusing the issue."

South African president Thabo Mbeki, who has questioned the link between HIV and AIDS and refused to speak openly about the disease, has often said he is concerned about the safety of such drugs. The faculty also called for the government to make public statements that unsafe sex is the main mechanisms of HIV transmission, and to provide testing, counseling and hospice care for those dying of AIDS.

Kristine Novak, New York

\title{
New NCl director appointed
}

The new year sees Andrew C. of a prostate cancer research program von Eschenbach begin his job as director of the National Cancer Institute (NCI), the largest institute of the National Institutes of Health (NIH). The head of the $\$ 3.8$ billion NCI is the only NIH director who is chosen by the president, and George W. Bush has selected von Eschenbach from the M.D. Anderson Cancer Center in his home state of Texas.

Von Eschenbach was largely unknown to the biomedical research community until his appointment. $\mathrm{He}$ is a cancer survivor himself and was the director of the Genitourinary Cancer Center and

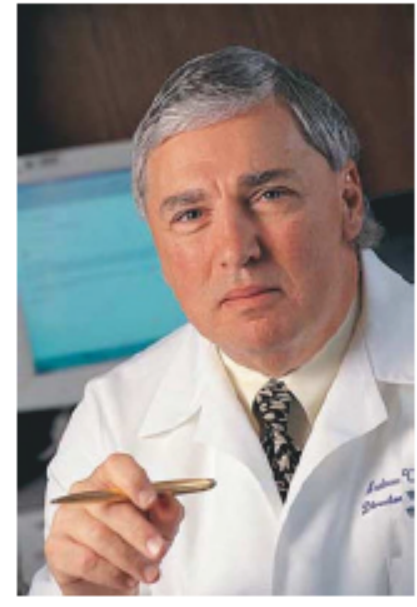

Friend of Bush, Andrew von Eschenbach at M.D. Anderson and president-elect of the American Cancer Society.

He replaces Richard Klausner who was widely regarded as a visionary leader credited with starting several programs to apply new molecular technologies to the treatment of cancer. Whereas Klausner's career has included basic research, Von Eschenbach has no background in bench research.

The NCI appointment comes at a time that several important positions at NIH are vacant. NIH has been withunderstanding and out a director since December 1999, when Harold Varmus left to head the Sloan-Kettering Cancer Institute in New York City. At one stage, it was rumored that John Mendelson, president of M.D. Anderson Cancer Center, was a candidate for the position.

Two neuroscience institutes are also without directors. Last month, Glen Hanson took a post as acting director of the National Institute on Drug Abuse following the resignation of Alan Leshner who left to become the Chief Executive Officer of the American Association for the Advancement of Science. Audry S. Penn has been acting director of the National Institutes of Neurological Disorders and Stroke since the resignation of Gerald Fischbach who has taken a position as vice president of Health Sciences at Columbia University in New York.

Laura Bonetta, Bethesda 